\title{
THE ANALYSIS THE EMERGENCY PROTECTION OF WATER RESERVOIRS IN OLSZTYN
}

\section{Wojciech Wiesner, Bogusław Kowalewski}

The University School of Physical Education in Wroclaw, Poland

\section{ABSTRACT}

Within the administrative boundaries of Olsztyn, there are 16 lakes and several artificial swimming facilities. They provide attractive conditions for water recreation and water sports. But are these conditions completely safe?

The aim of the study is to get familiar with the safety conditions of water reservoirs in Olsztyn in terms of opportunities for water recreation. In order to solve the addressed problem, the analysis of source materials has been performed, the field research has been conducted and the survey has been applied.

The outcome of the research includes the description of the recreational value of these water reservoirs, the identification of potential threats (internal and external) and the evaluation of logistic and emergency protection.

Key words: olsztyn reservoirs, water recreation, water rescue services.

\section{ARTICLE INFO}

PolHypRes 2015 Vol. 52 Issue 3 pp. 59-70

ISSN: $1734-7009$ elSSN: 2084-0535

DOI: $10.1515 /$ phr-2015-0017

Pages: 13, figures: 1 , tables: 2

page www of the periodical: www.phr.net.pl

Publisher

Polish Hyperbaric Medicine and Technology Society

\section{Rewiev article}

Delivery date: $25.06 .2015 \mathrm{r}$

Date of approval for print: $19.09 .2015 \mathrm{r}$ 


\section{INTRODUCTION}

The year 2012 brought fundamental changes in the safety systems both on the water and in the structure of water rescue services in Poland. These changes were the result of the Act on the safety of persons in water areas [1]. The changes implemented by the Act of 2011 and four regulations $[2,3,4,5]$, in a strategic way changed the organisation of emergency protection of Polish water areas.

Apart from the Voluntary Water Rescue Service [WOPR], so far the monopolist in this field, currently 108 entities having the approval of the Minister of Interior [6] now deal with water rescue services. In comparison with the situation that existed a few years ago, when only WOPR and several local organisations were responsible for safety of Polish waters, this is a huge number. The vast majority of registered organisations originate from WOPR and they are still associated with it. They account for over $60 \%$ of the total.

These are local and field offices of WOPR, as well as the headquarters of this association. Most of them are based in Mazowieckie province - 13. In contrast, most of the new organisations are registered in Łodzkie province -6 [7]. It is assumed that the legislator's intention was to create a market for emergency services, thus reducing the economic costs of maintaining the water safety services.

In our opinion, the fundamental objective of the changes implemented in the area of social safety should be the reduction of the number of drowning incidents and the enhancement of the feeling of safety among people relaxing on the water. Such an assumption has also an important axiological meaning, determined by the value of human life.

But has limiting the monopoly of WOPR over water rescue services and the creation of new entities dealing with the rescue services increased the level of safety? Such an analysis has not been carried out, neither before the introduction of the Act, nor after a few years of its functioning. We highlight this problem, because it is already high time to diagnose the effects of the discussed legal regulation and to thoroughly analyse it. Objective threats for bathers and persons relaxing on the water remain unchanged.

The Minister of the Interior exercises control over the activities of individual entities and assesses them in terms of legality, efficiency, efficacy and reliability. The functioning of the new system requires administrative control over the correct operation of the entities and an analysis of the consequences of these changes for public safety on the water.

In this report we analysed the current state of safety on Polish water areas. The analysis has been conducted on the example of Olsztyn, because this city is the capital of the region particularly rich in water reservoirs, and is attractive in terms of recreation and tourism.

The total area of lakes in Olsztyn is about 720 hectares, which represents almost $10 \%$ of the city area, and in the western part even $40 \%$ of the area [8] (Fig. 1). According to data from the City Office of Olsztyn [9], within the administrative boundaries of the agglomeration there are in fact 11 lakes and more than 200 small water reservoirs, 3 rivers and many artificial swimming facilities. They provide attractive conditions for water recreation and water sports.

But are the reservoirs in Olsztyn properly and effectively protected after the systemic transformation and legislative changes? Are these conditions fully safe? Has the growing market of water rescue services and safety on the water changed the real level of safety of persons relaxing on the water and their sense of safety? Are new entities able to offer a higher quality of services, especially in the field of education and cooperation with system units? Are they able to undertake the permanent emergency stand-by duties, etc.? First of all, the fundamental question should be posed - will the new legal situation influence the overall level of safety on Polish waters, and if so, how?

Fig. 1. Distribution of lakes in Olsztyn (Source: [10]). 
The aim of the study is to get familiar with the safety conditions of water reservoirs in Olsztyn in terms of opportunities for recreation on the water. In order to address the stated problem, the analysis of source materials has been performed, field research has been conducted and a survey has been applied. The outcome of the research includes the description of the recreational value of these water reservoirs, the identification of potential threats (internal and external) and the evaluation of logistical and emergency protection.

The content of the article is a continuation of the discussion and analyses conducted by the authors in this field [7].

\section{Characteristics OF NATURAL WATER} RESERVOIRS IN OLSZTYN

3 rivers flow through Olsztyn: Łyna, Wadąg and Kortówka. However, the number of lakes located within the administrative boundaries of the city is calculated differently by various sources. The above-mentioned program of the City Office mentions their being 11 lakes, but in the table characterising these reservoirs in terms of ecology it describes 13 lakes [9].

Wikipedia gives the number of lakes as being 15 including 13 with a surface area of over 1 hectare [8]. However, on other pages, under the heading Lakes in Olsztyn, Wikipedia gives the number of lakes as being 16 [10]. Similar calculations are provided by Bartnikowski [11], who states that Olsztyn is a city of sixteen lakes. For a complete picture of water potential of the city, in this study we have adopted the latter, the highest number (Table. 1).

The summary presenting possible uses of 16 Olsztyn lakes for bathing and water recreation purposes. The ranking takes into account the size of the surface of these lakes. The shaded fields indicate the water reservoirs used for bathing. Source: Own study based on [10].

\begin{tabular}{|c|c|c|c|c|c|}
\hline o. & Name of lake & Surface [ha] & $\begin{array}{l}\text { Maximum depth } \\
{[\mathrm{m}]}\end{array}$ & $\begin{array}{l}\text { Recreational } \\
\text { values }\end{array}$ & Use for bathing \\
\hline & Ukiel (Krzywe) & 412.0 & 43.0 & + & + \\
\hline & Kortowskie & 89.7 & 17.2 & + & + \\
\hline & Track (Trackie) & 52.8 & 4.6 & + & ice sailing \\
\hline & Skanda & 51.5 & 12.0 & + & + \\
\hline & Redykajny & 29.9 & 20.6 & + & + \\
\hline & Długie & 26.8 & 17.2 & + & + \\
\hline & Sukiel (private) & 20.8 & 25.0 & + & fishing \\
\hline & $\begin{array}{l}\text { Tyrsko (Gutkowskie, Zbzikowe, } \\
\text { Żbik) }\end{array}$ & 18.6 & 30.6 & + & + \\
\hline & Zgniłek & 6.0 & 0.0 & - & - \\
\hline 0 & Stary Dwór (Starodworskie) & 6.0 & 23.3 & - & fishing \\
\hline 1 & $\begin{array}{l}\text { Siginek (Kopytko,Podkówka, } \\
\text { Styginek) }\end{array}$ & 6.5 & 6.0 & - & fishing \\
\hline 2 & Czarne & 1.3 & 7.0 & - & - \\
\hline 3 & Żbik & 1.2 & no data & - & - \\
\hline 4 & Pereszkowo (Pyszkowo) & 1.2 & no data & - & - \\
\hline 5 & Mummel (Mumel) & 0.3 & approx. & - & - \\
\hline 6 & Modrzewiowe & 0.2 & no data & - & - \\
\hline
\end{tabular}


As can be observed on the basis of the above data, of 16 lakes that are located within the city boundaries, only 8 are suitable for recreational purposes and only 6 for bathing. These are: Lake Ukiel (Krzywe), Lake Kortowskie, Lake Skanda, Lake Redykajny, Lake Długie and Lake Tyrsko. Our findings are confirmed by the survey conducted in 2015 by the Olsztyn Internet Portal [12].

\section{THE ANALYSIS OF THE EMERGENCY AND LOGISTIC PROTECTION ON THE SELECTED RESERVOIRS IN OLSZTYN}

The largest and most popular place for bathing and water recreation is Lake Ukiel (Krzywe). Popular among the residents of Olsztyn are also swimming areas by Skanda, Długie and Kortowskie lakes [13] (Zaręba 2015). For the analysis we selected the swimming areas on the above-mentioned six lakes [11].

\section{Swimming area on Lake Ukiel}

The municipal beach by Lake Ukiel has achieved the status of being a representative swimming area in Olsztyn. The current name is Sports and Recreation Centre Ukiel. The whole complex consists of five facilities. All of them have lifeguards in attendance:

- Swimming area "Municipal Beach No. 1" is designated by means of the bridge permanently mounted to the bottom of the lake with dimensions $76 \times 38 \mathrm{~m}$, it is guarded by 3 lifeguards from June 1 to September 13, from 10:00am-6:00pm.

- Swimming area "Municipal Beach No. 2" is designated by means of floating bridges, the swimming area is $95 \times 25 \mathrm{~m}$, it is guarded by 3 lifeguards from June 26 to August 31, 10:00am6:00pm.

- Swimming area "Municipal Beach No. 3" is designated by means of floating buoys, measures $35 \times 25 \mathrm{~m}$, it is guarded by 2 lifeguards from June 26 to August 31, 10:00am-6:00pm.

- Swimming area "Sloneczna Polana" is designated by means of buoys, measure $50 \times 25$ $\mathrm{m}$, it is guarded by 2 lifeguards from June 26 to August 31, 10:00am-6:00pm. The beach is clean, grassy, not crowded, there are toilets and a volleyball court, however, there is no food service.

A marina "Sloneczna Polana" is nearby.

- $\quad$ The "Water playground" consists of around 50 inflatables including an obstacle course, catapults, swings, trampolines, slides, a 6-meter climbing wall and a volleyball court. This area measures $55 \times 45 \mathrm{~m}$ and is about 3 meters deep. The whole lot is anchored within a distance of about 15-20 meters from the shore. Having a surface area of around $2,000 \mathrm{~m}^{2}$, as many as 200 persons may play at the same time [14]. The playground is guarded by 3 lifeguards during the period from June 1 to September 13, from $10: 00 \mathrm{am}$ to $6: 00 \mathrm{pm}$ and at weekends from $10: 00$ am to $10: 00 \mathrm{pm}$.

- Emergency protection on all swimming areas of
Lake Ukiel was exercised by several entities in recent

years. In 2012 - Koordynator Terenowy Sp. z o.o.; in 2013 - WOPR of Warmia and Mazury province; in subsequent years, again Koordynator Terenowy Sp. z o.o.

According to our findings, there is very good cooperation between security services. The safety of persons relaxing at the water is ensured by, in addition to lifeguards, the following services:

- Police - two policemen from 10:00am to 6:00pm;

- City guard - constant radio connection with the City Supervisor;

- Motorboat Patrol operated by WOPR - 2 boats with 3 lifeguards in each, from10:00am to 6:00pm, from June 15 to the end of August;

- Medical Point operated by one paramedic, open from 10:00am to 6:00, in July and August;

- Security of the facility - monitoring and sound system, from 8:00am to 8:00pm - one employee, from 8:00pm to 8:00am - two employees;

- $\quad$ Sports and Recreation Center - motorboat and diving equipment.

After the opening of the Sports and Recreation Center in Ukiel earlier this year, the residents of Olsztyn, collectively come in order to use the very well equipped rentals, sanitary facilities and program attractions (serviced with emergency and medical protection). The city authorities have launched a special seasonal line of bus transport with major districts of the city. unguarded)

Swimming area on lake Skanda (one

1. Swimming area at the cliff on Lake Skanda a few years ago there was a comfortable pier there and a pleasant descent into the water, and a tree hanging from the cliff which served as a swing. Today the pier is gone and the tree finally broke, but the water is still not the worst. The advantage is a beautiful, sandy, steep cliff (former excavation) with a forest on the top; the disadvantage - lack of lifeguards and catering facilities.

2. Swimming area "Skanda" at Plażowa Street designated by means of floating buoys, measuring $25 \times 25 \mathrm{~m}$, secured by 2 lifeguards between June 26 and September 31, from 10:00am to $6: 00 \mathrm{pm}$. The area has a grassy beach, volleyball court and the possibility to rent water sport equipment, there is not much in the way of catering facilities however.

\section{(unguarded)}

Swimming area on Lake Kortowskie

Benefitting from a gently sloping bottom, water which heats quickly, plenty of space for sunbathing (grass), very good access and a close proximity to the university campus (shopping). The location's disadvantages include - the water is a little cloudy due to the muddy bottom and, owing to the fact that it hosts summer camps, part of the area has been separated of from the main area. 


\section{Swimming area on Lake Redykajny}

The beach on Lake Redykajny is a quite popular bathing place for families with children. Having clean water and no vessels on the lake, the beach is totally wild, without any facilities. Amateurs swimmers also benefit from the other beach located about 200 meters away, where there is less space for sunbathing, and the bottom immediately falls steeply.

\section{(unguarded)}

Swimming area by the bridge on Lake Długie

This area has spontaneously emerged relatively recently, upon the completion of the rebuilt bridge on the lake. With relatively few visitors, people can swim and sunbath in moderate comfort. There is a lack of any facilities and little space to spread blankets because all around there is tall pine forest, effectively blocking the sunlight.

\section{(unguarded) \\ Swimming area on Lake Tyrsko (Żbik)}

The lake was once famous for its perfectly clean water, and though still relatively clean today, such a comment is not without caveat. The area has two wild beaches (no bridges and lifeguard) and quite a few descents into the water through the flattened strip of rushes.

1. The beach is relatively little frequented due to its difficult access. Cars needs to be left at a nearby housing estate (without a freely accessible parking lot) and access is by foot through approx. 500 meters of forest.

2. Swimming area by the hotel Manor on Lake Tyrsko (Żbik) - this is another beach on this lake, it would be quite pleasant, if not for this hotel.

In the already cited studies conducted by the Olsztyn Internet Portal, the respondents most frequently mentioned the Municipal Swimming Area on Lake Ukiel. The opportunities for water recreation on these areas are the most encouraging. The full set of responses is shown in Table 2.

Summary of the results of a survey conducted by Olsztyn Internet Portal. The ranking contains only 9 items. The shaded fields indicate life-guarded swimming areas. Source: Own calculations based on [12]

\begin{tabular}{|c|c|c|c|}
\hline 0. & Place & $\begin{array}{l}\text { Number of swimming } \\
\text { areas }\end{array}$ & $\begin{array}{l}\text { Results of the survey } \\
{[\%]}\end{array}$ \\
\hline & Municipal beach on lake Ukiel & $\begin{array}{l}3 \text { swimming areas + } \\
\text { water playground }\end{array}$ & 36.62 \\
\hline & Municipal beach on Lake Tyrsko (Żbik) & 1 & 14.46 \\
\hline & Municipal beach on Lake Kortowskie & 1 & 11.08 \\
\hline & Beach Słoneczna Polana on Lake Ukiel & 1 & 8.00 \\
\hline & Beach on Lake Skanda & 1 & 7.69 \\
\hline & Grassy Beach on Lake Skanda & 1 & 7.69 \\
\hline & The beach by the hotel Manor on Lake Tyrsko (Żbik) & 1 & 5.54 \\
\hline & Beach on Lake Redykajny & 1 & 4.62 \\
\hline & Wild swimming area near the bridge on Lake Długie & 1 & 4.31 \\
\hline
\end{tabular}

According to our analysis, on Olsztyn lakes currently, 12 places are used for bathing and swimming. Life-guarded swimming areas constitute half of this number. In the 2015 bathing season, the sanitary and epidemiological station approved all the life-guarded swimming areas in Olsztyn, and within the whole Warmia and Mazury province it has approved a total of 12 swimming areas. The current announcement concerning the quality of water in swimming areas in the province can be found on the website of the Provincial SanitaryEpidemiological Station in Olsztyn [15].

All the life-guarded swimming areas were properly secured and equipped with the necessary rescue equipment in accordance with the Regulation of the Minister of Interior of February 27, 2012 on the requirements relating to rescue and auxiliary equipment, signaling and warning devices and medical equipment, medicines and sanitary articles in designated water areas [4]:

- rowing rescue boats,

- life buoys,

- lifelines on spinning wheel,

- sound tubes,

- information board, 
- radio station,

- rescue tubes,

- binoculars,

- $\quad$ elevated life-guard positions,

- mast with a set of flags,

- medical equipment, medicines and sanitary articles.

In the 2015 season, 46 incidents were registered on the swimming areas, in which water rescuers provided assistance to victims both in the water and on the land. In six cases, help was provided to people who were drowning or under water. The remaining events where traumatic in nature: wounds and bleeding (31), fractures, sprains, contusions (6), sting (1), chest pain (1) and one person reported missing. All these incidents had a positive ending and there was no tragedy [16].

\section{ANALYSIS OF SAFETY IN OLSZTYN SWIMMING POOLS AND WATER PARKS}

Indoor facilities are a perfect supplement to the recreational opportunities of open reservoirs. There are a total of five and they draw people seeking water based recreation. These include the Aquasfera Galeria Warmińska, the University Swimming Pool, the indoor swimming pool at Mariańska, the Sports and Recreation Centre swimming pool and the Indoor swimming pool at the Olsztyńska Szkoła Wyższa [17].

\section{Aquasfera Galeria Warmińska}

The Water Recreation and Sports Center in Aquasfera from July 1, 2014 has been called Aquasfera Galeria Warmińska. It is the first swimming pool in Poland, which has a title sponsor, who will financially contribute to the maintenance of the pool in exchange for promoting his brand. Aquasfera in Olsztyn consists of both a sport and recreation part, as well as SPA with the sauna, rehabilitation centers and fitness centre.

The sport part is dominated by the Olympic swimming pool measuring $50 \times 25$ meters with a movable bottom from 0 to 2 meters with an auditorium for 1,500 seats. In addition, there is a pool to warm up and for swimming classes $(25 \times 8.5 \mathrm{~m})$ with an auditorium possessing seating for another 146 people.

The recreational part has a pool of different shapes, with many attractions - cascade, water slides, lazy river, underwater massage, whirlpool, Jacuzzi and a children's pool with a depth from 0.3 to 0.5 meters $[18,19]$.

This facility functions in accordance with the procedures established on the basis of the audit conducted in 2012 [20]. Emergency protection was implemented by: Koordynator Terenowy Sp. z o.o. (2012), Jarocki Tomasz Multigrupa (2013) and WOPR of Warmia and Mazury province (2014-2015). Although the entities were changing, they generally centered on the same group of Olsztyn lifeguards with qualifications and rescue experience specified by the Act.

\section{University Swimming Pool}

The swimming pool of the University of Warmia and Mazury in Olsztyn consists of a sports pool, a pool for swimming classes, dry and steam saunas, a complex of three whirlpools with showers, gym with a fitness room and catering facilities.

The sports pool measures $25 \times 21 \mathrm{~m}$ ( 8 tracks) and has an auditorium. The pool for swimming classes measures $12.5 \times 6 \mathrm{~m}, 0.9 \mathrm{~m}$ deep [21]. This pool has not been subject to a safety audit. Emergency protection is implemented by Koordynator Terenowy Sp. z o.o. (20122015). Emergency interventions at the university pool this year alone include: a nose bleed, a fall on the stairs in to the Jacuzzi (resulting in a hip injury), and on two occasions loss of consciousness/syncope [16].

Sports and Recreation Centre - The complex of indoor sports facilities I at Głowackiego Street [22].

The facility includes two indoor swimming pools - a big pool measuring $25 \times 12.5 \mathrm{~m}$ and a small pool measuring $10 \times 4 \mathrm{~m}$, a sports hall measuring $30 \times 18 \mathrm{~m}$ and a fitness room. There are organised activities: swimming lessons for babies, children, adults, aerobics, martial arts, cheerleaders, rehabilitation and physiotherapy exercises.

Sports and Recreation Centre - The complex of indoor sports facilities II at Mariańska street

The facility consists of: a swimming pool measuring $25 \times 8 \mathrm{~m}$ and a sports hall measuring $38 \times 20 \mathrm{~m}$. At the swimming pools of the Sports and Recreation Center at Głowackiego Street and Mariańska Street, the emergency protection is organised directly by the operator, i.e. The Sports and Recreation Centre Olsztyn. Wyższa

Indoor swimming pool at Olsztyńska Szkoła

The indoor swimming pool at OSW has a pool measuring $25 \times 10.5 \mathrm{~m}$. It can be simultaneously used by 30 people. The offering here includes swimming classes for adults, aqua aerobics, aqua senior and aqua amazons. In the facility there is also a Jacuzzi, sauna, gym and massage rooms.

Emergency protection is directly organised by the operator, i.e. Olsztyńska Szkoła Wyższa.

\section{Characteristics OF ORganisations SECURING WATER FACILITIES IN OLSZTYN}

In the above mentioned Act on the safety of persons in water areas, the conditions that an organisation must meet in order to undertake rescue services are specified in the introduction. The consent of the Minister of the Interior is obtained through an administrative decision after providing the following information in the application:

- $\quad$ name of entity, registered office and address;

- area, on which water rescue services are to be performed;

- number of lifeguards and their qualifications useful for water rescue;

- list of specialist equipment, means of transport and communication;

- $\quad$ sources of financing of planned activities;

- the scope of planned training for lifeguards and instructors;

- list of personnel and equipment necessary for training and examination [1]. 
Among the 108 organisations authorised to perform water rescue services in Poland [6], in the area of the Warmia and Mazury province, six such organisations have been registered.

1. Mazury Volunteer Ambulance Service, ul. Nabrzeżna 15, 11-500 Giżycko;

2. Koordynator Terenowy Sp. z o.o., ul. Żniwna 2a, 10-811 Olsztyn;

3. Voluntary Water Rescue Serices of Warmia and Mazury province, ul. Polna 16, 10-059 Olsztyn;

4. Mazury Rescue Services, Okartowo, 12-250 Orzysz;

5. Volunteer Fire-brigade in Szeligi Water rescue unit, ul. Kolejowa 10A, 19-300 Ełk;

6. Elbląg Volunteer Water Rescue Services, ul. Robotnicza 68, 82-300 Elbląg.

For comparison, Mazowieckie, Łodzkie and Malopolskie provinces each have more than 10 registered organisations [7].

Only two of these 6 organisations (marked in bold) compete with each other in securing the reservoirs in Olsztyn. WOPR of Warmia and Mazury province providing local service, and Koordynator Terenowy Sp. z o.o. that operates throughout the country. In 2013 The Recreation and Sports Center Aquasfera was protected by an external company from Lower Silesia [6].

\section{SUMMARY AND CONCLUSIONS}

Water rescue services in Poland have entered a phase of social changes which is a consequence of systematically transforming that which existed in the 1980s. The possibility of appointing new operators in the field of water rescue services and their dynamic development resulted in the emergence of the rescue services market.

Public service providers (e.g. WOPR) operating in competitive environments often lose the contests for the provision of rescue services. Private entities are typically more efficient, because they are able to offer higher quality services for the same funds. Higher economic efficiency increases profits by reducing the delivery costs, which in turn enables investment or increases in individuals' salaries. Conversely, lower efficiencies result in price increases and decreases in salaries [23].

However, in the operation of organisations dealing with rescue services, the economic motives (profit) cannot prevail over ideological motives (values). There are already worrying signs that not all of the newly formed organisations duly perform their obligations [24]. These are warning signals.

At the root of such pathologies is the motif of generating material benefits, at any price. We believe that the failure to comply with ethical standards by some service providers is associated with a low quality of services [25]. Rescuing a drowning man cannot be treated only in terms of commercial and marketing activities [7].

So, are water reservoirs in Olsztyn properly and effectively protected after these systemic transformations and legislative changes? All swimming areas and pools in Olsztyn are currently being serviced by two local organisations - local WOPR and a private rescue company. Emergency services of these organisations are selected in the course of a tendering procedure by individual operators.

Provincial WOPR guarantees the status quo, while the company Koordynator Regionalny Sp. z o.o. is co-managed by WOPR instructors, which also does not imply a change for the worse. In both entities the same, local lifeguards are employed. It is similar in facilities managed by the Sports and Recreation Centre, university or OSW. It should therefore be concluded that the entities functioning on the market are able to offer at least the same high quality rescue services as before the reform.

The analysis conducted on the Olsztyn water reservoirs indicates that these conditions are completely safe for swimming and bathing. From the analysed media reports it can be concluded that the sense of safety felt by the people relaxing on the water has not been disturbed.

One can only express doubt as to whether new organisations are able to deal with permanent stand-by rescue duties, cooperate with units of the system, and whether they can carry out actions in the field of education, etc.? We are currently looking for answers for the posed questions. We will be able to get answers only after a thorough inspection of the functioning of the entities conducted by the minister. The analysis of these data will be credible after the system introduced by the Act has functioned for a period of several years.

\section{BIBLIOGRAPHY}

1. The Act of 18 August 2011 on the safety of persons in water areas, Journal of Laws No. 208, item 1240.

2. Regulation of the Minister of Interior of 23 January 2012 on minimum requirementsregarding the number of lifeguards providing permanent control over designated water areas, Journal of Laws of 27 January 2012.

3. Regulation of the Minister of Interior of 6 March 2012 on methods of marking and securingwater areas and the examples of prohibition, injunction or information signs and flags, Journal of Laws of 19 March 2012.

4. Regulation of the Minister of Interior of 27 February 2012 on requirements relating to rescueand auxiliary equipment, signaling and warning equipment and medical equipment, medicinesand sanitary articles designated water areas, Journal of Laws of 9 March 2012.

5. Regulation of the Minister of Interior of 21 June 2012 on the training in water rescue, Journal of Laws of 2 July 2012.

6. Entities authorized to perform rescue taskshttps://www.msw.gov.pl/pl/bezpieczenstwo/nadzor-nad-ratownictwe/10071,podmioty-uprawnione-dowykonywania-zadan-ratownictwa-gorskiego-i-wodnego.html

[cited 2015-11-04]

7. Wiesner W., Kowalewski B. The characteristics of entities responsible for water rescue services in Poland,W: State, prospects and development of rescue, physical culture and sports in the XXI century. Vol.1, Rescue / ed. Marek Napierała, Aleksander Skaliy, WSG Bydgoszcz 2015

https://pl. wikipedia.org/wiki/olsztyn [cited 2015-11-04].

9. Programme of environmental protection for Olsztyn for years 2011-2014, with the perspective of the year 2018, Olsztyn, 2011, http://www.olsztyn.eu/fileadmin/dokumenty-strategiczne/zal-do-XVIII-284-151211-program-ochrony-srodowiska.pdf [cited 2015-11-04] https://pl.wikipedia.org/wiki/jeziora_w_olsztynie [cited 2015-11-04].

10. https://pl.wikipedia.org/wiki/jeziora_w_olsztynie [cited 2015-11-04].

11. Bartnikowski A., Olsztyn - the city of 16 lakes, http://naszawarmia.pl/56973,olsztyn-miastem-16-jezior.html\#axzz3qEC1hQcM [cited 2015-11-04]

12. Which bathing beach to choose. http://olsztyn.wm.pl/292122,ktore-kapielisko-wybrac-i-gdzie-najlepiej-plazowac. html\#axzz3psFaMCN3 [cited 2015-11-04].

13. Zaręba K., Whereabouts in Olsztyn can one bathe? The list and overview of Olsztyn's bathing beaches http://olsztyn.wm.pl/289882,gdzie-kapac-sie-w- 
olsztynie-lista-i-subiektywny-przeglad-olsztynskich-plaz.html\#axzz3qED6KzcQ [cited 2015-11-04].

14. Kamińska I. (2015), A water playing ground on an Olsztyn beach, http://www.olsztyn.com. pl/artykul,wodny-plac-zabaw-na-plazy-w-olsztynie, 18733.html [cited 2015-11-04]

15. http://www.wsse.olsztyn.pl [cited 2015-11-04]

16. Work logs of lifeguards on the bathing beaches of Ukiel lake and swimming pools, Koordynator Terenowy Sp. z 0.0., 2015.

17. http://infobasen.pl/baseny/olsztyn.html [cited 2015-11-04].

18. http://www.aquasfera.olsztyn.eu/pl [cited 2015-11-04]

19. http://www.osir.olsztyn.pl/pl/home-pl-pl/item/410-aquasfera-galeria-warminska

[cited 2015-11-04].

20. Safety audit for the Water Centre of Sport and Recreation in Olsztyn, prepared by a team supervised by W. Wiesner, OSiR Olsztyn, 2012

21. http://www.uwm.edu.pl/basen [cited 2015-11-04]

22. http://www.osir.olsztyn.pl/pl/baseny [cited 2015-11-04]

23. Samuelson P.A., Nordhaus W.D. (2005), Economics, PWN, Warsaw.

24. Kleczaj J. (2013), Privatization of water rescue forces - better quality or 'any old how'?, I Congress of Water Safety in Szczecin in 2013

25. Wiesner W. (2015), Client's safety as an essential attribute of recreational services, an article in Zeszyty Naukowe WSB.

dr hab. Wojciech Wiesner prof. AWF

The University School of Physical Education in Wroclaw

al. Ignacego Jana Paderewskiego 35

51-612 Wrocław 